\title{
No fee increases: Cascades and calamities
}

So much has been written, over the past 11 months, about '\#feesmustfall' and '\#nofees', that there is little, if anything, left to say. The Council on Higher Education has presented its report to the Minister of Higher Education; the Presidential Commission continues with its work; and Universities South Africa has made representations to the Minister and to the Parliamentary Portfolio Committee on Higher Education. All that is needed is a decision (now arrogated from university councils it would seem) - and the means of dealing with whatever will follow the decision.

However, in the welter of the situation faced by the South African education system, and on the implications of the decisions that need to be made, two issues seem to have been overlooked.

The first of these is what might be called 'the cascade effect'; the second is the calamity of the discarded.

Despite denials and various alternative explanations, it remains true that, on 23 October 2015, President Zuma announced that there would be no fee increases for university students in 2016. The consequences and dangers of this announcement are well known - but it was not, then, immediately obvious (although perhaps it ought to have been) that the demand for no fee increases so readily acceded to would very quickly transmogrify into 'free higher education for all'. Economic impossibility and social justice irrationality notwithstanding, both issues now lie at the core of the problem.

Yet there is a significant implication that is not often addressed. Just over 1 million students are enrolled in the higher education system in South Africa. That they are enrolled makes them a small but privileged part of society: they are about $1 \%$ of the young people who entered primary school 12 years ago. Setting that privilege aside (while not ignoring the reality that as few as $50-60 \%$ of those students will eventually graduate), the demand that there should be not only no fee increases but, possibly, no fees at all, leads to a rather different view of the situation.

In this context, and that of current and unexpected political uncertainty, consider what might happen if a 'no fee increase' or a 'no fees at all' demand were to be met. Irrespective of how socially unjust it is (the wealthy will be the greatest beneficiaries of a 'no fee' higher education system), it will have serious consequences for the quality of South African university education. Egregious though that may be, it will not be the worst scenario for the South African education system. The international rankings of our universities have already shown a lowering of the status of South African universities - a result of, according to some experts, the persistent underfunding of higher education by the South African government. This is, however, just a start of the challenges that the South African post-school education system must be prepared to face.

If the most privileged young people should become entitled to low-cost or free higher education, why would the (currently) rather less privileged 800000 or so students in the Technical and Vocational Education Training (TVET) sector not be entitled - even more entitled - to free education?

\section{The cascade begins.}

If, then, the more and most privileged pay fixed, or no, fees, why then should the most deserving - the young people at school - pay anything at all? The cascade ends with low cost or free education for all, while the economy faces a growth rate close to zero - a situation that will continue until more well-educated and skilled young people enter and contribute to that same economy.

Some observers and interpreters have proposed that the student protests, burnings and broader mayhem, have to do with higher education's callous alienation of the relatively few young people who are enrolled as students. These observers do not, of course, subscribe to the idea that young people who enter the higher education system are privileged. Nor, for the most part, do they acknowledge the predominant class of the protesters, who speciously claim to be the representatives and champions of the poor. Claiming 'no increases', or free higher education, is not a plea for the poor - it is a hollow middle-class avoidance of one of the most critical issues: the need for comprehensive support for smart, deserving young people who need, not just their fees, but also their living to be assured.

Which leads to the calamity. Which will almost certainly turn out to be more serious.

All told, there are some 2 million learners in the university, TVET and community college sector. Yet, in the same age group (18-25), there are over 3 million young people who are NEETs - 'not in employment, education or training'.

These are the 3 million young people who are adrift and seemingly without options - and who do not receive, amidst the fees debate, the attention or the financial support that they deserve. They beg for food at street corners; they become, out of desperation, members of gangs; or else, in the most dire circumstances, they are already in prison. Of their conditions, the self-proclaimed socio-economic warriors are either unforgivably ignorant or, equally unforgivably, careless.

If ever there was a clear insight into the real values of protesting students (many, the sons and daughters of chief executive officers, vice chancellors and Members of Parliament), then it is this - that they ignore, or at the very least overlook, the severe and long-term social and economic implications of the NEETs. Free education, or education without fee increases, is not about social justice. It can only be a very sad statement about ignorance, carelessness of social and economic realities, and the promotion of some other, yet to be revealed (and possibly self-serving), end.

What does all this say about universities, in these difficult times? Perhaps two things: they clearly do not do enough to teach vital, core values; and some of their leaders have abandoned academic principles in favour of expedience when principle is most needed.

HOW TO CITE: Butler-Adam J. No fee increases: Cascades and calamities. S Afr J Sci. 2016;112(9/10), Art. \#a0176, 1 page. http://dx.doi.org/10.17159/ sajs.2016/a0176 